\title{
Applications of 3D printing in healthcare
}

\author{
Helena Dodziuk \\ Institute of Physical Chemistry PAS, Warsaw, Poland \\ Kardiochirurgia i Torakochirurgia Polska 2016; 13 (3): 283-293
}

\begin{abstract}
$3 \mathrm{D}$ printing is a relatively new, rapidly expanding method of manufacturing that found numerous applications in healthcare, automotive, aerospace and defense industries and in many other areas. In this review, applications in medicine that are revolutionizing the way surgeries are carried out, disrupting prosthesis and implant markets as well as dentistry will be presented. The relatively new field of bioprinting, that is printing with cells, will also be briefly discussed.

Key words: 3D printing, applications in healthcare, hearing devices dentistry, surgery, medical devices.
\end{abstract}

3D printing (3DP) developed as a modification of an old inject printer. Today, it is rapidly expanding: almost every week new printers and printing materials offering novel possibilities as well as new exciting applications appear. Healthcare, automotive, aerospace and defense industries are the most vivid areas of 3DP applications. This review will present applications in medicine that are revolutionizing the way operations are carried out, disrupting prosthesis and implant markets as well as dentistry, to name but a few. The relatively new field of bioprinting, that is printing with cells, will also be briefly discussed. As will be presented below, numerous applications of 3DP in medicine belong to personalized medicine. For instance, implants or prostheses are 3D printed for a specific user's body, optimizing the technology to work for an individual, not an average user as with most mass produced products. It should be stressed that contrary to better known cases of personalized medicine dealing with molecules of drugs and their corresponding active sites, and hence on the nanoscale, the 3DP applications developed precisely for a patient's needs are on the macroscale.

3DP applications in medicine are booming. They include customized implants [1] and prosthetics [2], medical models [3] and medical devices [4] that revolutionize healthcare and may even disrupt many areas of traditional medicine. The comment by Robert Elsenpeter from the ModernDental network [5] - "The future might sound crazy, but it's real -

\section{Streszczenie}

Drukowanie w 3D jest stosunkowo nową, burzliwie rozwijającą się dziedziną wytwarzania, która znalazła liczne zastosowania w medycynie, przemyśle samochodowym, kosmicznym i obronnym oraz wielu innych dziedzinach. W tym przeglądzie zostaną omówione zastosowania w medycynie, które rewolucjonizują sposób przeprowadzania operacji chirurgicznych, zakłócają działanie rynków implantów i protez oraz stomatologii. Przedstawiona zostanie również względnie nowa dziedzina biodruku, tj. druku komórkami.

Stowa kluczowe: druk 3D, zastosowania w medycynie, aparaty słuchowe, stomatologia, chirurgia, narzędzia.

and it's right around the corner" - refers to dentistry, but it is valid for the whole domain.

A brief summary of the applications of 3D printing in medicine is provided by Christopher Barnatt on the YouTube channel ExplainingTheFuture [6].

In the healthcare market, several factors influence global $3 \mathrm{D}$ printing, such as the advances in technology and improvement in the healthcare infrastructure, on the one hand, and an increase both in the percentage of the aging population and in the investment in research and development sector, on the other. The domain is rapidly expanding. A 3D printer of the Polish company Zortrax is presented in Figure 1.

According to Wikipedia [7], Additive manufacturing or 3D printing [8] is a process of making a three dimensional solid object of virtually any shape from a digital model. What is very important, 3DP allows one to manufacture in a single run objects that are impossible to obtain by any other fabrication method. Objects with holes, sometimes filled with a dense network as in bone implants, are good examples of such capabilities (Fig. 2, [9, 10]). Manufacturing objects consisting of several parts that move with respect to each other or consisting of interpenetrqating structures in one run is also impossible by any other method.

Speaking very briefly, 3DP consists in laying down successive layers of material in different shapes, each one printed directly on top of the previous one according to a com-

Address for correspondence: Helena Dodziuk, Institute of Physical Chemistry PAS, 44/52 Kasprzaka St, 01-224 Warsaw, Poland,

e-mail: hdodziuk@gmail.com

Received: 20.08.2016, accepted: 22.08.2016. 


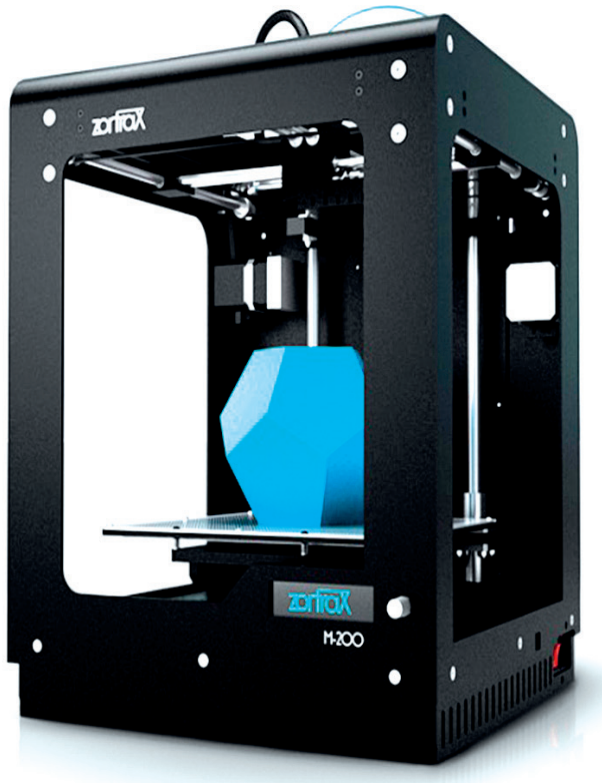

Fig. 1. 3D printer of the Polish company Zortrax [9] highly evaluated by users of the 3Dhubs site [10] @ Zortrax

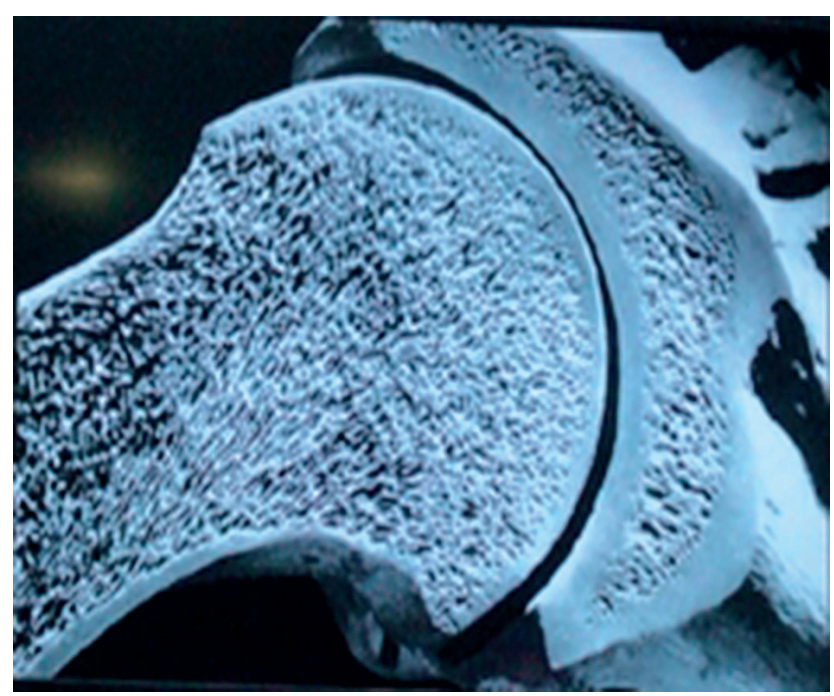

Fig. 2. 3D printed bone structure featuring porous bone structure presented at 3D PrintShow Berlin 2015 (c) H. Dodziuk

puter program. 3DP as additive technology is distinct from traditional manufacturing techniques, which are subtractive processes in which material is removed using methods such as cutting or drilling.

The Wikipedia article [7] states that the beginning of 3DP dates back to the 1980s while Mary Gehl [11] dug even further in the past to the 1970s without giving any references to the claim. Interestingly, the French General Electric Company (now Alcatel-Alsthom) and CILAS (The Laser Consortium) abandoned in the early 1980s the applications of their patent for stereolithography [12], one of the most important processes in 3DP, in which layers are added by curing [13] with ultraviolet light laser [14]. The claimed reason was "due to lack of business potential" [15]. One of the most important founding fathers of 3DP is Chuck Hull [16], who founded 3D Systems Corporation [17] and developed a prototype system based on stereolithography. As a matter of fact, Hull's definition of the process as a "system for generating three dimensional objects by creating cross-sectional patterns [18] of the object to be formed" was similar to that of the process that had been earlier invented by Kodama [19, 20]. Hull's great contribution is the design of the STL (STereoLithography) file format [21], widely accepted by 3D printing software, as well as the digital slicing and infill strategies commonly applied in many processes today.

The term "3D printing" was coined in 1995 by Prof. Ely Sachs at MIT, who authored a project of modifying an inkjet printer in such a way that a binding solution was extruded onto a bed of powder, rather than applying ink onto paper as was done in the old inkjet printers. Today the terms $3 D$ printing (3DP) and additive manufacturing (AM) are used interchangeably. In addition, desktop manufacturing, rapid manufacturing or rapid prototyping are sometimes used to describe this method of manufacturing.

3D models to be printed, as Hull's STL files, are made either with a computer aided design (CAD) package [22], via a 3D scanner [23] or by a plain digital camera and photogrammetry [24] software. In medicine, they are created using X-ray or tomography images transformed into the STL format. The fewest errors are created with the CAD method. They can be corrected before printing, allowing one to verify the design of the object before it is printed [25].

It should be stressed that today there are at least 18 methods applied in additive manufacturing, some of them with several modifications [9, 26-28]. Printing materials are also highly diversified. They are called filaments when they involve plastic (polylactic acid [PLA], acrylonitrile butadiene styrene $[A B S]$, polyamide, nylon, polyethylene terephthalate [PET], etc.). However, metallic powders, rubber, glass, sand, carbon fibers and graphene as well as organic materials (such as cells, wood, and chocolate), actually almost anything, can be used for 3DP. An important step after an object has been printed using most methods is postprocessing, since, due to the layering involved in the process, the printouts have rough surfaces. Recently, the company Polymaker got a strong boost [29] on the crowdsourcing site Kickstarter for their project making postprocessing obsolete. They pledged \$100 000 support and got over \$433000 for a completely new 3DP filament \& desktop machine, which should dramatically improve the surface quality of $3 \mathrm{D}$ printed parts, which would not require postprocessing.

Advances in 3DP will be achieved not only by development of new printers and filaments but also by progress in scanners and 3DP software. Today commercial CAD packages are not simple to use and require special knowledge. This hampers not only the 3DP applications in healthcare but also the whole 3DP consumer market. Another area pertaining to the application of 3DP in healthcare is development of high-quality specific materials for 3D printed prostheses, implants and diverse medical devices. 
Until few years ago, 3DP was used mainly in so-called rapid tooling and prototyping enabling engineers to design and improve by the designing process tools and prototypes. However, today this method of manufacturing is intensively applied in automotive, aerospace, military, engineering, dental and medical industries. There are also numerous applications in fashion, footwear, jewelry, eyewear, food, and many other areas. Of special interest is 3DP with cells, called bioprinting, which at present is bringing the first applications and holds great promise.

The economist, social theorist, writer and activist Jeremy Rifkin, the author of 20 books on the impact of scientific and technological development on the economy, the workforce, society, and the environment, claims that 3D printing is one of the pillars of the third industrial revolution [30].

\section{DP in healthcare}

It is recognized that medical uses for 3D printing, both actual and potential, will bring revolutionary changes [31, 32]. They can be organized into several broad categories, including: creation of customized prosthetics, implants, and anatomical models, tissue and organ fabrication; manufacturing of specialty surgical instruments, pharmaceutical research regarding drug fabrication, dosage forms, delivery, and discovery [33] as well as manufacturing medical devices. Benefits provided by application of 3D printing in medicine include not only the customization and personalization of medical products, drugs, and equipment, but also cost-effectiveness, increased productivity, the democratization of design and manufacturing, and enhanced collaboration [32, 34-36].

The market research firm Gartner claims [37] that the applications of 3DP in healthcare are already in the mainstream. It is certainly true for hearing aids and partly for dental devices, but development in areas such as implants and prostheses and planning of surgery seems more complicated. Moreover, numerous, nontrivial applications such as modeling of fetal heart defects [38] and glasses for the blind and visually impaired [39] discussed below indicate how difficult it is to make predictions in this area. It seems that the applications in healthcare can be divided into at least three categories: mainstream or close to them (hearing aids and dental devices), those that are widely used but still are not in the mainstream (including the greater part of the prosthesis market or manufacturing medical devices such as stethoscopes [40] or books for blind [41]), and those in an early stage of development but capable of entering the mainstream (such as bioprinting with cells or $4 \mathrm{D}$ printing, that is $3 \mathrm{D}$ printing in which the printed object changes its shape after being made [42]), and which are hoped to revolutionize medical 3DP applications in future. Still another area is 3DP of drugs [43].

In general, the applications of 3DP in medicine are diverse, and in some areas it has (as in the hearing aids market) or may (as in the prosthetics fragment) disrupt the whole market.

\section{Application of 3DP in hearing aids [44]}

There are numerous media reports about spectacular 3DP applications on Earth and in space, but a quiet and spectacular revolution in the manufacturing of hearing aids went practically unnoticed [45]. As Rakesh Sharma from Forbes puts it, it is "The 3D Printing Revolution You Have Not Heard About”. According to Phil Reeves, author of a report on the 3D printing industry, in 2013 there were more than $10,000,0003 \mathrm{D}$ printed hearing aids in circulation worldwide. Much more are in use today. 3DP transformed the manual, labor-intensive industry into an automated one that is fast and patient-oriented. Before introducing 3DP into this domain, manufacturing of hearing aids looked like a kind of artisanal production; it took more than a week. Today the 3DP process that involves scanning, modeling and printing can take less than a day.

In this domain, the revolution was initiated by a Belgium-based company, Materialize [46], in collaboration with a Swiss hearing aids producer. They started the 3DP applications in this field by developing Rapid Shell Modeling, or RSM, back in 2000. On the other hand, in 2005 EnvisionTec [47] developed its own process (Digital Shell Modeling, DSM) while Denmark-based Widex manufactured the world's smallest aid [48] with CAMISHA (Computer Aided Manufacturing of Individual Shells For Hearing Aids). Recently (February 2016) [49], Starkey Innovation Expo took place in Las Vegas. Faukes from Starkey said that the company produces $98 \%$ of hearing aids using stereolithography (SLA) printers, while for medical reasons and complicated form factors, the remaining $2 \%$ are not manufactured using 3DP. Interestingly, the application of 3DP has not driven the cost of the hearing aids down, probably because few companies dominate the market.

It should be stressed that the applications of 3DP in hearing aids manufacturing was analyzed as an example of its disruptive effect on established companies [50].

In Poland, the Institute of Physiology and Pathology of Hearing in Kajetany uses 3DP not to produce implants but for modeling and teaching purposes [51].

\section{Applications of $3 D$ printing in dentistry $[52,53]$}

The first industrial applications of 3DP were in the fields of rapid tooling and rapid prototyping. Thus, its use in dentistry, where single, personalized objects were manufactured, was an obvious next step. Today, by combining oral scanning, CAD/CAM design and 3D printing, dental labs can accurately and rapidly produce crowns, bridges, plaster/ stone models, and a range of orthodontic appliances such as surgical guides and aligners. Instead of uncomfortable impressions, a 3D scan is taken, which is later transformed into a 3D model and sent to be 3D printed. The printed model can be used to create a full range of orthodontic appliances, delivery and positioning trays, clear aligners and retainers. Moreover, the models can be conveniently stored digitally as 3D CAD (Computer Assisted Design) files. 3DP allows one to digitize the whole workflow, dramatically 
accelerating production times and significantly increasing production capacity. In addition, they allow one to eliminate physical impressions and the storage of models.

There were rapid changes in dental labs in 2015 [54]: "changes came fast and furious, particularly because it was the year when the International Dental Show occurred and previewed some of the most cutting-edge solutions coming to the dental lab world".

1. New denture workflows have been introduced everywhere. "While the full potential of digital tools on the denture workflow has yet to be realized, 2015 offered some tantalizing glimpses at some of the possibilities. Suddenly, full dentures produced entirely from digital files don't seem like such a far away option".

2. More user-friendly modules change CAD.

3. In 2015, for the first time "printing entirely finished dental prostheses and restorations with the push of a button seemed to come closer to reality". With the dental printer that can print layers of different material over one another [55] and FDA approved denture material for 3DP, [56] "3D printing flirts with the future".

4. Disruptive character of 3DP for the industry: With 3DP, dentists are introducing labs into their offices and both printers, and materials bring revolutionary changes to labs, dentists and dental technicians. This demands permanent education on the part of dental technicians on one hand with some new exciting opportunities on the other.

5. The number of dental labs in the US is decreasing. Is it related to $3 \mathrm{DP}$ ?

There are numerous new 3D printers for dental and orthodontic labs not only from the 3DP giant Startasys [57] but also from smaller companies such as Zenith 3D Printing Systems [58], Envision [59], AXSYS, Valplast, etc. As mentioned, the new, first FDA-approved printing material [56] and a new material that kills bacteria [60] have to be mentioned here, too.

An interesting, not well-known type of surgical 3D printed devices used in dental practice is surgical guides [61] that are also 3D printed.

To summarize, new inexpensive printers for small, medium and larger dental labs and clinics with novel userfriendly operation modes as well as new materials secured wide applications of 3DP in dentistry in the USA. The trend will undoubtedly be followed in other countries. Interest-

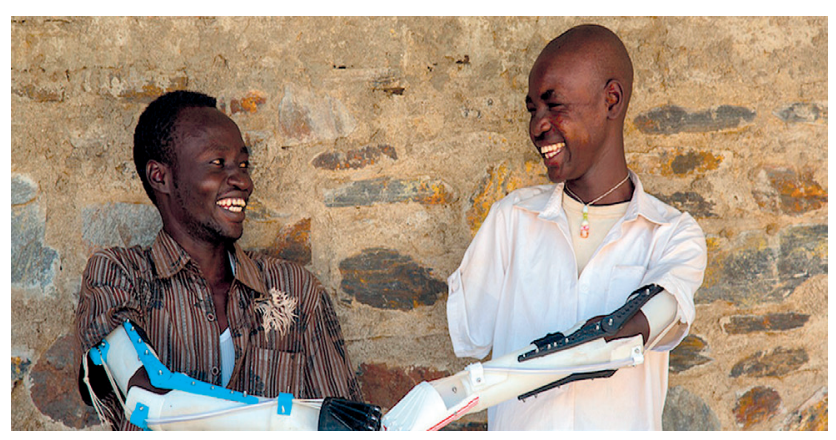

Fig. 3. Courtesy of www.NotImpossible.com [2] ingly, the first, to our best knowledge, liability case concerning 3DP (of dental aligners) has been submitted to a court in California [62].

\section{D printed prostheses}

3D printed prostheses can be customized according to individual taste and cost much less than traditional alternatives. The limb can also be re-designed to be more stylish with added tattoos and patterns [63].

$3 \mathrm{D}$ printed prostheses are a good example of the influence this technique can exert since, on the one hand, they are inexpensive, and, on the other, they are fully customized to the wearer. In addition, they are more comfortable than the traditional prostheses and can be manufactured in a day [64]. Low costs of the 3D printed limb prostheses are especially important in prosthetics for children, since they outgrow the prostheses fast. Moreover, stretchable and expandable 3D prosthetics may soon be available for children that could "grow" with the child. One can find on the Internet "DIY" assistive devices that can be printed by virtually anyone, anywhere. Taking into account the high cost of the traditional prostheses, this leads to a revolution disrupting the prosthesis market.

One of the first and mostly publicized example is the hand prosthesis developed by the then 17-year-old high school student Easton LaChapelle [65], who wanted to help a 9-year old girl whose parents could not afford a new, larger prosthetic hand for $\$ 80000$. His 3D printed prosthesis, controlled by a headband equipped with EEG (electroencephalography) through which brain waves controlled the movement of the prosthesis, costed less than $\$ 500$. He posted his designs online [66] for anyone to refine, repurpose, and use. Currently, Easton works with NASA on the construction of robots. He also wants to help people paralyzed from the waist down by building external prostheses and exoskeletons.

An idea to manufacture inexpensive $3 \mathrm{D}$ printed prostheses for victims of land mines in Asia and Africa and other amputees led to the creation of e-NABLE [67]. As they put it: e-NABLE is a network of passionate volunteers using $3 \mathrm{D}$ printing to give the world a "Helping Hand". The community is "an amazing group of individuals from all over the world who are using their 3D printers to create free 3D printed hands and arms for those in need of an upper limb assistive device". It "is made up of teachers, students, engineers, scientists, medical professionals, tinkerers, designers, parents, children, scout troops, artists, philanthropists, dreamers, coders, makers and every day people who just want to make a difference". They create, innovate, re-design and share 3D-printable prosthetics. The e-NABLE "Family Tree" [68] shows just how powerful open source, collaborative design can be.

In a slightly different mode of operation, NotImpossible [2] provides low-cost solutions by creating or modifying accessible solutions, such as 3D printing, on an open-source DIY platform and manufactures devices to help war victims or the impaired poor (Fig. 3). 
The 3D printed leg prostheses seem to be less publicized, but several models of the prostheses have been proposed (see, for instance [69, 70]). Andiamo [71] is a company specializing in orthotics for children, mainly leg prostheses.

3D printed eye prostheses are worth mentioning here [72].

An interesting novel aspect of the prosthesis market is their aesthetics. Joel Gibbard, CEO of Open Bionic [73], stated at the PrintShow Berlin 2015 that before going into the business he launched an inquiry asking amputees about their demands. In addition to obvious answers, like light weight and simple operation, there was no demand, especially from young amputees, that the prosthesis should look like a real hand; they preferred it to look like a Star Wars gadget. And so the prostheses on their webpage look like they come from Marvel, Disney Frozen or Star Wars (Fig. 4). In a similar mood, Samiya Parvez from the company Andiamo mentioned answered the question: "What do you do with an orthopedic corset?" "You can either hide it under a dress or decorate it with Svarowsky crystals and proudly wear it".

Exciting 3D printed hand prostheses designed by children can be seen at the Quartz website [74].

The story of a face cancer healed patient, Eric Monger, who had to live with a part of the face removed and received a partly 3D printed prosthesis (Fig. 5), is especially touching [75].

\section{Implants, excluding dental ones and those used in hearing aids}

Today several manufacturers produce high-quality replacements/implants for spine [76, 77], hip [78], pelvis [79], trachea $[80,81], 75 \%$ of a man's skull [82], and other body parts. In 2014, the company 4WEB 3D printed and implanted 3000 spinal truss systems [83].

On the other hand, a great part of this domain is still a kind of craftsmanship, like the jaw implant for an 83-yearold woman manufactured in 2012 [84]. The implants are patient-specific as concerns their size and shape determined on the basis of medical imaging data such as X-ray for bones, computed tomography (CT) $[85,86]$ and magnetic resonance imaging (MRI) [87], for bone, soft tissue, and blood vessels. The customization of the $3 \mathrm{D}$ printed implants to the patient represents a true personalization.

$3 \mathrm{D}$ printed implants have also been applied in the treatment of such illnesses as diabetes [88] and arthritides [89].

It should be stressed that there exists an open source free software package, 3D Slicer [90], for visualization and medical imaging computing that can be applied for 3D printing. It is a software platform allowing one to analyze and visualize medical images and carry out research. The software available on multiple operating systems - Linux, MacOSX and Windows - supports multi-modality imaging including, magnetic resonance imaging (MRI), computed tomography (CT), ultrasonography (US), nuclear medicine, and microscopy and is not restricted to a specific organ. Moreover, it contains a bidirectional interface to devices. There is no restriction on use, but Slicer is not approved for

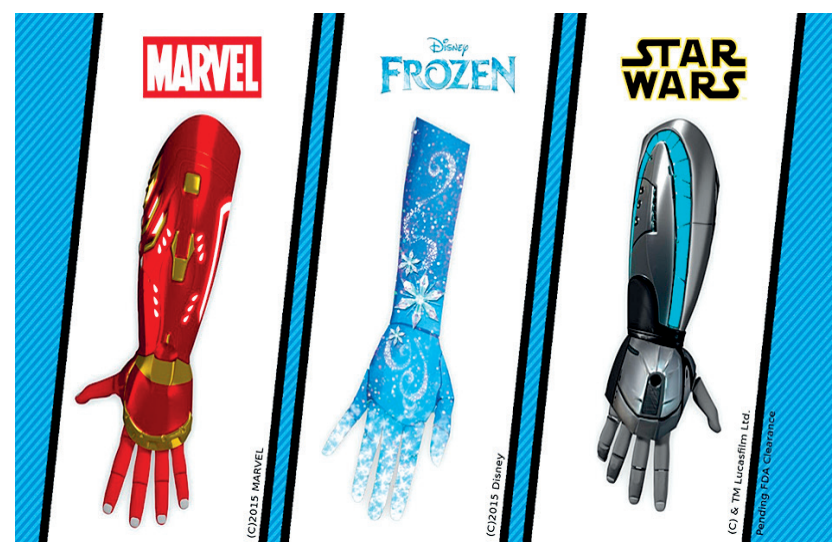

Fig. 4. Hand prostheses from Open Bionics. Courtesy of Open Bionics [73]

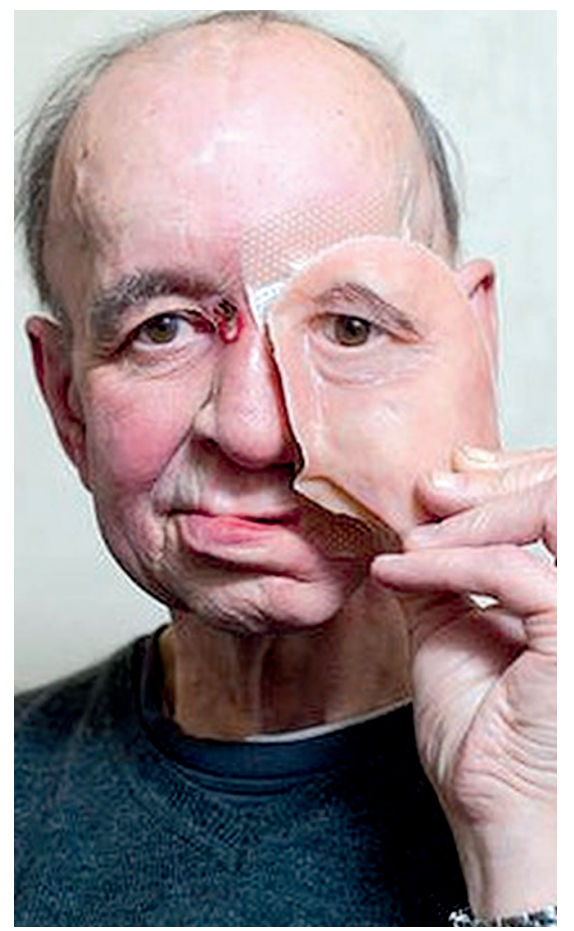

Fig. 5. Cured from face cancer, Eric Monger received a partial prosthetic face, a part of which was 3D printed (c) Geoff Pugh http:// geoffpugh.photoshelter.com/index

clinical use and is intended for research. Permissions and compliance with applicable rules are the responsibility of the user.

In addition to their time- and money-saving capabilities, 3D printers are known to be able to induce several desirable properties in such medical implants. These properties can include complex internal structures, customized elements, and drugs that could foster the healing process.

As mentioned above, surgical procedures involving several types of implants have been carried out. In Poland, the pioneers were probably Dr Marcin Elgalal and Prof. Bogdan Walkowiak from Lodz University of Technology and Prof. Marcin Kozakiewicz, the head of the Maxillo-facial Surgery Clinics in Lodz, who established the Laboratory of Indi- 
vidual Medical Implants [91] in Lodz Technopark. First they made craniofacial implants [92]. They also use a 3D printed titanium net in reconstruction of the orbital floor [93]. The methods developed for craniofacial implants will be applied by the same group for carrying out virtual necropsy [94].

3D printed implants are applied more and more in Poland. There is a lot of such information in, sometimes local, newspapers. The reconstruction of the jaw bone of a patient was carried out in the Department of Maxillofacial and Plastic Surgery at the University Hospital in Bialystok. A mandibular bone replacement was implanted in WAM Hospital in Lodz.

An application of 3D printed implants for crippled animals [95] became probably much more popular than those for humans. It is estimated that in one year about 10000 dogs suffering from injuries or degeneration of their hind leg ligaments received the implants in Europe and the U.S., according to a press release from 3DS. This large number is partly due to much less stringent legal regulations of medical procedures for animals than for humans and the fact that dog owners cover the costs of the operations. In Poland, prosthetic dog limbs are made and implanted at Warsaw University of Technology [96].

\section{Virtual surgical planning}

Imaging techniques are important in medical practice. Introducing 3DP brings an essential improvement in surgical planning. Computed tomography (CT) and/or MRI images lead to a detailed picture of internal organs and anatomical parts. Their 3D printed replicas reproduce the size, weight and texture of organs, allowing surgeons to rehearse complicated procedures on 3D models. The Japanese company Fasotec, bought by Stratasys, developed a Biotexture Wet Model [97] realistically mimicking such
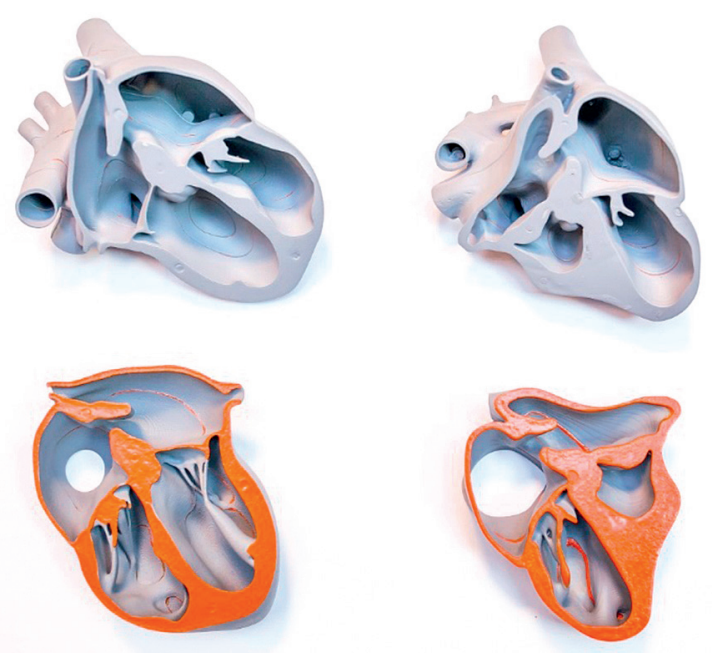

Fig. 6. Two cardiac 3D models opened at the level of the fourchamber view (left, normal fetal heart; right, the heart exhibiting hypoplastic left heart syndrome based on aortic atresia). Courtesy of Dr. M. Wiecheć MD, PhD organs as lungs that allows surgeons and students to practice the operations to be carried out.

Today planning surgery with the help of 3D printed models is a widely used procedure. To name but a few, it has assisted full face transplants [98, 99], the first adult-tochild kidney transplant [100, 101], removal of a kidney [102] or liver tumor [103] in hospitals [104, 105], and acetabular reconstructive surgery [106].

\section{D printed models in teaching in healthcare}

Such models are also used in several areas of medicine in various workshops - in particular, the aforementioned workshops in Poland at the Center for Hearing and Speech in Kajetany [51] (Fig. 3) and in the Lesser Poland Workshops in Ultrasonography [107] (Fig. 6). The use of the Biotexture Wet Model of the lung in training of medical students [97] has already been mentioned.

\section{DP of medical devices}

The number of 3D printed medical devices is enormous and is growing steadily. They include an inexpensive high quality stethoscope developed for poor hospitals in the Gaza Strip [40] (the project is open source), a 3D printed winch used in endovenous laser therapy (EVLT) for the treatment of varicose vein removal [108] which is presented by the Polish company Zortrax on YouTube [109], a Multi-Sensory Perception Simulator (SPPS) device, developed by the Center for Hearing and Speech in Kajetany, Poland [110], glass frames you can order [111] or 3D print yourself [112] or 3D printed lenses. The latter were a special challenge in view of the layered structure of the $3 \mathrm{D}$ printouts, but the glass barrier has been broken [113].

The marketing of the 3D printed titanium device FastForward Bone Tether Plate, which facilitates less-invasive foot surgery and eliminates the need to drill through bone, has been approved for use by the FDA in correction surgery to treat bunions [114].

Older people remember heavy and clumsy plaster casts sometimes decorated by patients with drawings and inscriptions. Today's 3D printed casts are light and attractive [115]. Orthoses are 3D printed by the Polish company Fucco [116] (Fig. 7).

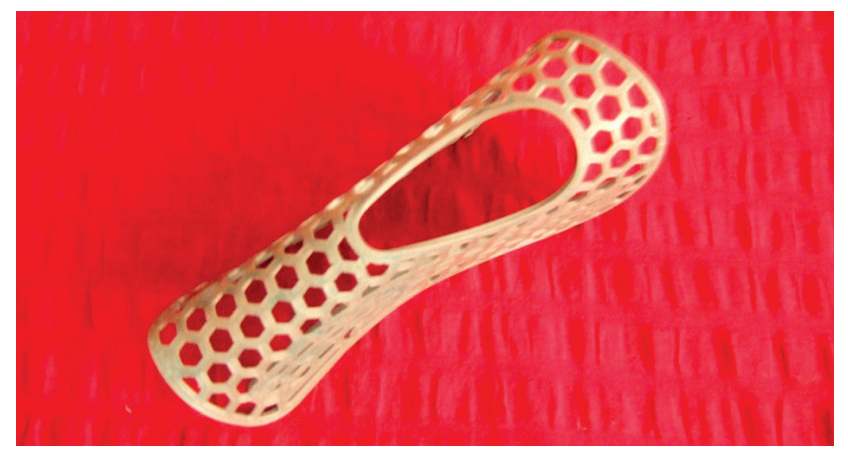

Fig. 7. Orthosis 3D printed by Fucco [116] @ H. Dodziuk 
A Polish company presented an exciting project of Parsee glasses [39] (Fig. 8) that could help visually impaired persons. The glasses consist of a 3D printed frame equipped with an IP (internet protocol) camera with photo button, headphone, and battery enabling the user to recognize and make sense of the world around him or her. By pushing the button a photo is made of an object or person and sent to the app in the cellphone to be recognized. Then, after the recognition, the information on text, shapes, colors and faces is heard by the person in the headphone. At present, a new lighter version of the glasses is being developed.

The presented prostheses, implants, and medical devices are only a small fraction of those proposed. They show (1) the full potential of personalization typical for this domain; (2) how the costs of the devices are sometimes dramatically lowered by applying 3DP as the manufacturing method. However due to monopolization by a few companies, the hearing device market has not shown any fall in prices; (3) the creativity induced by 3DP. Some of the devices proposed, such as the somewhat offbeat idea of the glasses for the vision impaired [39], could be manufactured using another method, but the idea happened to come to people active in 3DP who took advantage of the rapid prototyping that this method of manufacturing provides.

\section{Bioprinting - printing living tissue using cells as ink}

Manufacturing a human tissue by 3D printing cells is an exciting, booming area of prospective applications of 3DP [117-120]. The main future aim of 3D bioprinting is to reduce the shortage of supply in the organ donor market. However, the present achievements are more modest: the important application so-called lab-on-the-chip, that is a high-throughput 3D-bioprinted tissue model exVive3D Liver for research, drug discovery and toxicology [121], has been proposed. The recently announced possibility of bioprinting using stem cells opens new possibilities in this domain [120]. The world's first ever [122] "thaw and use" human mesenchymal stem cells bioink is offered by the Swedish startup company Cellink [123] and the American stem cell company RoosterBio [124].

Feasible and standardized materials such as cell-friendly biomaterials are prerequisites of the 3D bioprinting applications. Until today, flat tissues such as skin [125], tubular structures (such as trachea or urethra/bladder) [126], and hollow and complex solid organs such as liver [127] have been 3D bioprinted. Chinese researchers reported the 3D bioprinting of tissues of kidney [128], ears and livers [129], although they seem not to be implantation-ready. Studies on bioprinting of bones [130], cartilage and muscles [131], and other tissues are being conducted.

Also, there is a new interesting material, self-healing bio-glass that can be applied as 3D printed cartilage replacement [132].

3D bioprinting [117] was started by Dr. Anthony Attala from Wake Forest Institute for Regenerative Medicine [133], who applied 3DP to manufacture organ tissues of heart and kidney [134] and by Gabriel Villard from Oxford University, who developed a bioprinter [135] and later, by printing two layers of different cells, for the first time observed changes of specimens after the printing that were later called 4D printing [136]. Recently, Dr. A. Atala's group announced construction of an integrated tissue-organ printer (ITOP) that can fabricate stable, human-scale tissue constructs of any shape. The researchers demonstrated capabilities of the ITOP by fabricating mandible and calvarial bone, cartilage and skeletal muscle [137].

One of the most active companies in the 3D bioprinting domain is Organovo. Today it is not possible to 3D bioprint any implantable human organ, but at Organovo, they have printed liver and kidney tissues. On the basis of the liver tissue consisting of primary human hepatocytes, stellate, and endothelial cell types, which are found in native human liver, they developed their amazing lab-on-chip, named the exVive3D Liver Model [138], aiming at drug testing that is stable for at least 42 days and much more effective than standard 2D liver cell culture systems offered by industry [139].

The cosmetic company L'Oréal launched cooperation with Organovo to 3DP skin models for cosmetic testing [140] instead of using humans or animals.

Out of several 3D bioprinters announced, there is a lowcost bioprinter, INKREDIBLE, by the Swedish startup CELLINK, costing $\$ 5000$ for the less expensive model or $\$ 9000$ for the more sophisticated one and using their own bioink with their own cells [141]. This printer allowed CELLINK to achieve an amazing result in which up to $98 \%$ of cells are alive when using their own bioink on their 3D printer.
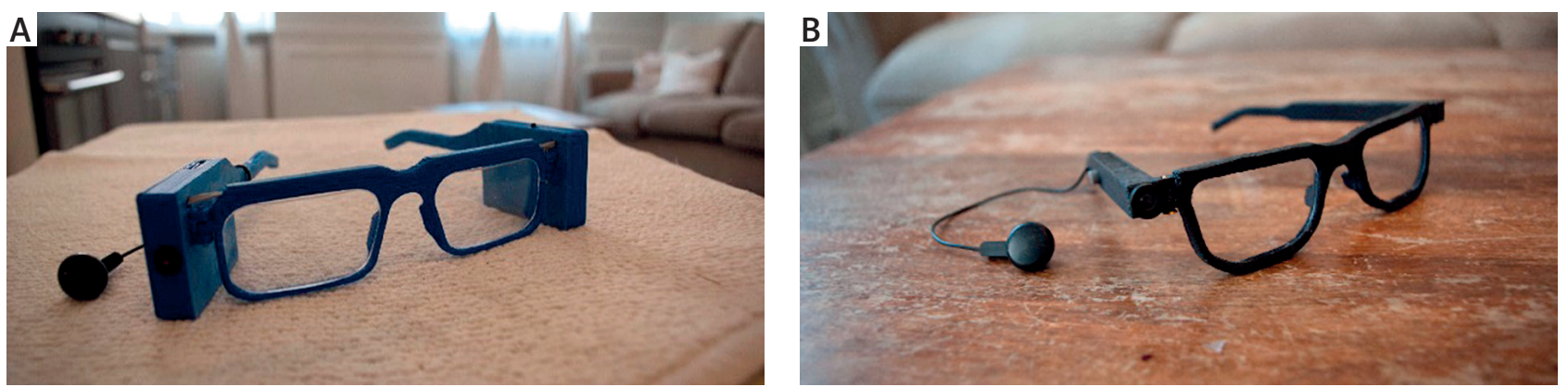

Fig. 8. A prototype of Parsee glasses (A). The company is working on miniaturizing it (B) (C Parsee company [39] 


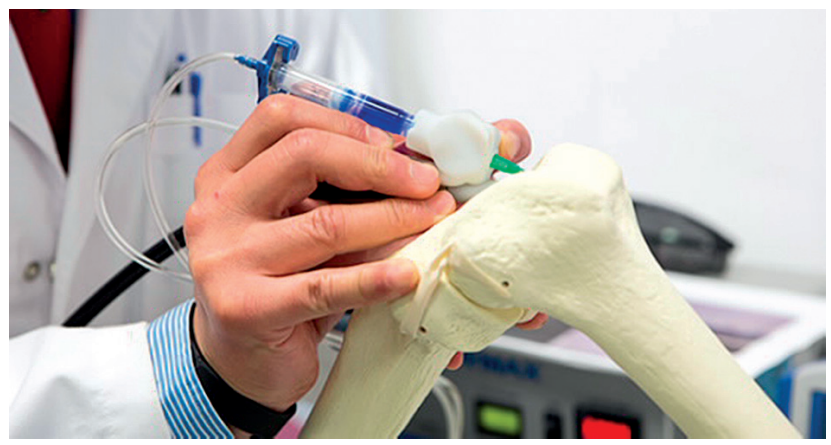

Fig. 9. Carrying a special healing bioink, a biopen being used on a bone model @ University of Wollongong, Australia

Not exactly a bioprinter but a device called Biopen allows surgeons to repair damaged bone and cartilage by "drawing" new cells directly onto bone in the middle of a surgical procedure [142] (Fig. 9).

3D printed organs for transplantations are still beyond reach. A Chinese researcher at Hangzhou Dianzi University, Xu Mingen, developer of the "Regenovo" bioprinter, predicted that fully functional printed organs may be possible within the next 10 to 20 years [143].

\section{Printing drugs [35]}

Extending their idea on the applications of 3D printing in chemistry, Lee Cronin's group applied their 3D printed reactionware to print the drug ibuprofen [144]. On the one hand, several applications of drug printing, e.g. for printing nonstandard doses for children or the elderly, have been proposed. On the other, taking into account the possibility of drug abuse, sharp words of criticism have been expressed $[145,146]$.

The possibility to $3 \mathrm{D}$ print drugs using downloadable pharmaceutical recipes piped directly into an appropriate 3D printer will have huge implications for the pharmaceutical industry in the same way music downloads have disrupted the music industry. This example shows what types of serious legal problems 3D printing raises.

The first 3D printed drug, Sprintam (levetiracetam, for epilepsy treatment), produced and marketed by Aprecia Pharmaceuticals, has obtained U.S. Food and Drug Administration (FDA) approval [147]. 3DP enables very porous pills to be manufactured, allowing for high drug doses in a single pill. Such a pill dissolves quickly and can be ingested easily [148].

\section{Conclusions}

3DP is widely used in healthcare. The domain of hearing aids is the first manufacturing branch fully overtaken by 3DP, and dentistry seems to be following suit. Implants and prostheses, the application of models in virtual surgical planning and teaching in healthcare, traditional and novel medical devices, 3DP of drugs - all these are rapidly developing areas of the 3DP applications in medicine. In most fields they offer considerably less expensive alternatives to the classical devices and procedures, release creativity accelerated by the ease of prototyping of novel devices and help through diagnostics and medical procedures. Think about the effect of virtual surgical planning or that of inexpensive limb prostheses presented above. An important feature of 3DP is its contribution to personalized medicine. According to Wikipedia, "the term has risen in usage in recent years given the growth of new diagnostic and informatics approaches that provide understanding of the molecular basis of disease, particularly genomics" [149]. One could call it personalized medicine on the nanoscale. 3DP offers personalized medicine on the macroscale, since implants and prostheses and numerous devices for medical use are patient-specific.

Apart from the tissue model exVive3D Liver developed by Organovo [150], 3D bioprinting is still in the development phase, since 3D bioprinted organs are beyond our reach. But it certainly will bring revolutionary changes in medicine. Introduction of new (bio)printers and (bio)compatible materials will accelerate medical applications of 3DP.

To speed up research and development in this area, the American National Institutes of Health $(\mathrm{NIH})$ created the $\mathrm{NIH}$ 3D Print Exchange Internet website [151] that provides open, comprehensive, and interactive access for searching, browsing, downloading, and sharing biomedical 3D print files, modeling tutorials, and educational material. Several websites allow one to download free files e.g. of limb prostheses.

The future of applications of 3DP in medicine is bright. We will witness the extension and refinement of old and development of new spectacular applications. Sometimes, the development will disrupt the whole field, as has happened with the hearing aids market without bringing price reductions [152], but in general 3DP will revolutionize a huge part of healthcare.

\section{Disclosure}

Authors report no conflict of interest.

\section{References}

1. Mendoza HR. Surgeons Create 3D Printed Custom Implant to Restore Pelvis after Resection. https://3dprint.com/91580/3d-printed-pelvic-implant/, 2015, accessed 11 Aug. 2016.

2. http://www.notimpossible.com/, accessed 11 Aug. 2016.

3. Molitch-Hou M. 3D Printing Enables Medical Models with Blood, Guts, \& All. http://3dprintingindustry.com/news/3d-printing-enables-medicalmodels-with-blood-guts-all-44186/, 2015, accessed 14 Aug. 2016.

4. http://envisiontec.com/trends-in-3d-printing-of-customized-medical-devices/, accessed 11 Aug. 2016.

5. Elsenpeter R. 10 things you need to know about 3D printing. http://www. dentalproductsreport.com/dental/article/10-things-you-need-knowabout-3d-printing, accessed 11 Aug. 2016.

6. Barnatt C. Medical 3D Printing. https://www.youtube.com/watch?v=P2 peq82e8is, 2013, accessed 11 Aug. 2016.

7. 3D printing. http://en.wikipedia.org/wiki/3D_printing, accessed 26 Febr. 2013.

8. Cummins $\mathrm{K}$. The rise of additive manufacturing. http://www.theengineer. co.uk/issues/24-may-2010/the-rise-of-additive-manufacturing/, 2010, accessed 11 Aug. 2016.

9. https://zortrax.pl/, accessed 11 Aug. 2016.

10. https://www.3dhubs.com/trends, accessed 11 Aug. 2016.

11. Gehl M. The Implications of 3D Printing. http://www.khouse.org/articles/2012/1078/, 2012, accessed 4 March 2013. 
12. Stereolithography. https://en.wikipedia.org/wiki/Stereolithography, accessed 11 Aug. 2016.

13. Photopolymer. https://en.wikipedia.org/wiki/Photopolymers, accessed 11 Aug. 2016.

14. Mendoza RH. Alain Le Méhauté, The Man Who Submitted Patent For SLA 3D Printing Before Chuck Hull. http://3dprint.com/65466/reflections-alainle-mehaute/, 2015, accessed 14 Aug. 2016.

15. Interview d'Alain Le Méhauté, l'un des pères de l'impression 3D. http:// www.primante3d.com/inventeur, accessed 11 Aug. 2016.

16. Chuck Hull. https://en.wikipedia.org/wiki/Chuck_Hull, accessed 11 Aug. 2016.

17. 3D Systems. https://en.wikipedia.org/wiki/3D_Systems, accessed 11 Aug. 2016.

18. Apparatus for production of three-dimensional objects by stereolithography. https://www.google.com/patents/US4575330, accessed 11 Aug. 2016.

19. Kodama H. A Scheme for Three-Dimensional Display by Automatic Fabrication of Three-Dimensional Model. 1981, J64-C, 237.

20. Kodama H. Automatic method for fabricating a three dimensional plastic model with photo hardening polymer. Rev Sci Instr 1981, 52, 1170

21. STL (file format). https://en.wikipedia.org/wiki/STL_\%28file_format\%29, accessed 11 Aug. 2016.

22. Computer-aided design. https://en.wikipedia.org/wiki/Computer_aided_ design, accessed 11 Aug. 2016

23. Hand-held laser scanners. https://en.wikipedia.org/wiki/3D scanner\# Hand-held_laser_scanners, accessed 11 Aug. 2016.

24. Photogrammetry. https://en.wikipedia.org/wiki/Photogrammetry, accessed 11 Aug. 2016.

25. Jacobs PF. Rapid Prototyping \& Manufacturing: Fundamentals of Stereolithography; Society of Manufacturing Engineers 1992.

26. Types of 3D printers or 3D printing technologies overview.http:// 3dprintingfromscratch.com/common/types-of-3d-printers-or-3d-printing-technologies-overview/, accessed 11 Aug. 2016.

27. Comparison between $3 \mathrm{D}$ printing and traditional manufacturing processes for plastics. https://www.sculpteo.com/en/3d-printing/3d-printing-andtraditional-manufacturing-processes/, accessed 11 Aug. 2016.

28. What is 3D printing? http://3dprinting.com/what-is-3d-printing/, accessed 11 Aug. 2016.

29. PolySmooth \& Polysher: 3D Prints Without Layers. https://www.kickstarter. com/projects/polymaker/polysmooth-and-polysher-3d-prints-without-layers, accessed 11 Aug. 2016.

30. Rifkin J. http://www.thethirdindustrialrevolution.com/, accessed 14 Aug. 2016.

31. Ventola CL. Medical Applications for 3D Printing: Current and Projected Uses. P T 2014; 39: 704-711.

32. Schubert C, van Langeveld MC, Donoso LA. Innovations in 3D printing: a 3D overview from optics to organs. Br J Ophthalmol 2014; 98: 159-161.

33. Klein GT, Lu Y, Wang MY. 3D printing and neurosurgery: ready for prime time? World Neurosurg 2013; 80: 233-235.

34. Banks J. Adding value in additive manufacturing: researchers in the United Kingdom and Europe look to 3D printing for customization. IEEE Pulse 2013; 4: 22-6.

35. Ursan I, Chiu L, Pierce A. Three-dimensional drug printing: a structured review. J Am Pharm Assoc (2003) 2013; 53: 136-144.

36. Gross BC, Erkal JL, Lockwood SY, Chen C, Spence DM. Evaluation of 3D printing and its potential impact on biotechnology and the chemical sciences. Anal Chem 2014; 86: 3240-3253.

37. Gartner. Gartner Says Medical Applications Are Leading Advancement in 3D Printing. http://www.gartner.com/newsroom/id/3117917, accessed 14 Aug. 2016.

38. Grunewald SJ. Doctors use 3D Printing to Safeguard an Unborn Baby's Life. https://3dprint.com/99905/3d-printing-to-safeguard-stetfetus/, 2015, accessed 11 Aug. 2016.

39. http://www.parsee.org/, accessed 11 Aug. 2016.

40. Goehrke SA. Made in Gaza: Glia Project Offers Open Source, Low-Cost, Locally 3D Printed Medical Supplies. http://3dprint.com/95097/project-gliagaza-strip/, 2015, accessed 11 Aug. 2016.

41. Molitch-Hou M. Classic Kids Books Made Tangible for the Blind with 3D Printing. http://3dprintingindustry.com/news/classic-books-made-tangibleblind-3d-printing-66332/, 2016, accessed 14 Aug. 2016.

42. Choi CQ. '4D-Printed' Objects Change Shape After They're Made. http:// www.livescience.com/53477-shape-shifting-4d-printed-objects.html?li source=LI\&li_medium=more-from-livescience, 2016, accessed 11 Aug. 2016.

43. Chakravorti B. 3 ways in which a $3 D$ printer may one day save your life. https://www.washingtonpost.com/news/innovations/wp/2016/03/07/3- ways-in-which-a-3d-printer-may-one-day-save-your-life/, 2016, accessed 11 Aug. 2016

44. Sharma R. http://www.forbes.com/sites/rakeshsharma/2013/07/08/the-3dprinting-revolution-you-have-not-heard-about/\#959ebaa21e12, 2013, accessed 14 Aug. 2016.

45. Sharma R. The 3D Printing Revolution You Have Not Heard About. http:// www.forbes.com/sites/rakeshsharma/2013/07/08/the-3d-printing-revolution-you-have-not-heard-about/\#2ca7b85f21e1, 2013, accessed 11 Aug. 2016.

46. http://www.materialise.com/, accessed 11 Aug. 2016.

47. http://envisiontec.com/3d-printing-industries/hearing-aid/, accessed 11 Aug. 2016

48. 3D printing helps develop the world's smallest hearing aid. http:// www.3ders.org/articles/20130103-3d-printing-helps-develop-the-worldsmallest-hearing-aid.html, accessed 11 Aug. 2016.

49. Starkey Innovations Expo Focuses on Technology, Marketing, and Purpose. http://www.hearingreview.com/2016/02/starkey-innovations-expo-focuses-technology-marketing-purpose/, accessed 14 Aug. 2016

50. Sandstrom C. Adopting 3D Printing for manufacturing - The case of the hearing aid industry. ratio.se/app/uploads/2015/12/cs_3dprinting_hearingaid_262.pdf, accessed 14 Aug. 2016.

51. Cochlear implant surgical workshop $-19^{\text {th }}$ Window Approach Workshop in Kajetany. http://whc.ifps.org.pl/2015/01/warsztaty-szkoleniowe-z-zakresuchirurgii-implantow-slimakowych-xix-window-approach-workshop-waw-w kajetanach/, accessed 19 Sept. 2016

52. https://www.dentalproductsreport.com/3d-printing/11614, accessed 11 Aug 2016.

53. http://www.dentalproductsreport.com/dental/article/10-things-you-needknow-about-3d-printing, accessed 11 Aug. 2016

54. The top 5 dental lab trends of 2015. https://www.dentalproductsreport com/lab/article/top-5-dental-lab-trends-2015, accessed 11 Aug. 2016.

55. Stratasys debuts new 3D printer for larger labs. https://www.dentalproductsreport.com/lab/article/stratasys-debuts-new-3d-printer-larger-labs, accessed 11 Aug. 2016

56. FDA approves 3D printable denture base material. http://www.dentalproductsreport.com/dental/article/fda-approves-3d-printable-denture-basematerial, accessed 11 Aug. 2016.

57. Objet30 OrthoDesk. http://www.stratasys.com/industries/dental/objet30orthodesk, accessed 11 Aug. 2016.

58. http://www.zenith3d.co.kr/eng/, accessed 11 Aug. 2016.

59. http://envisiontec.com/3d-printing-industries/dental/, accessed 11 Aug. 2016.

60. New 3D-printed teeth also kill bacteria. http://www.dentalproductsreport. com/dental/article/new-3d-printed-teeth-also-kill-bacteria, accessed 11 Aug. 2016

61. 3D Printer Creates Digital Solution for Surgical Guides. http://www.stratasys.com/resources/case-studies/dental/guide3d, accessed 11 Aug. 2016.

62. Kain CRM, Price JM, Reilly PH. Five of the Top Drug \& Device Developments in 2015. http://www.faegrebd.com/five-of-the-top-drug-device-developments-in-2015, accessed 11 Aug. 2016

63. How About Them Gams: 3D Printing Custom Legs. http://www.business week.com/articles/2012-05-03/how-about-them-gams-3d-printing-cus tom-legs, accessed 11 Aug. 2016.

64. The Future is Here: 3D Printed Prosthetics. http://dealingwithdifferent. com/3d-printing-prosthetics/, accessed 14 Aug. 2016.

65. Meet Easton LaChappelle, The 19-Year-Old Luminary Building A Cheaper, Better Prosthetic Limb. http://uproxx.com/technology/easton-lachappelleluminary/, accessed 11 Aug. 2016.

66. Robotic Arm Files. http://theroboarm.com/, accessed 11 Aug. 2016.

67. http://enablingthefuture.org/, accessed 14 Aug. 2016.

68. Our "Visual Tree". http://enablingthefuture.org/2014/03/13/our-visual-tree/, accessed 4 Aug. 2016.

69. Bionic Leg Produces Normal Gait [video]. http://healthtechinsider.com/ 2015/06/08/bionic-leg-produces-normal-gait-video/, accessed 14 Aug. 2016.

70. Sprey K. 3D printed Exo-Prosthetic leg designed to be affordable - and beautiful. http://www.gizmag.com/exo-prosthetic-leg-3d-printing/35297/, accessed 14 Aug. 2016

71. http://andiamo.io/, accessed 14 Aug. 2016

72. 3D printing "can produce up to 150 prosthetic eyes per hour". http://www. dezeen.com/2013/11/26/3d-printed-prosthetic-eyes/, accessed 11 Aug. 2016

73. http://www.openbionics.com/, accessed 11 Aug. 2016.

74. Kids are 3D printing their own "superhero cyborg" prosthetic arms. (Water cannons optional). http://qz.com/600405/kids-are-designing-theirown-3d-printed-superhero-cyborg-prosthetic-arms/, accessed 11 Aug. 2016. 
75. How doctors printed my new face. http://www.telegraph.co.uk/news/ 9962798/How-doctors-printed-my-new-face.html, accessed 11 Aug. 2016.

76. First operation worldwide with individualized 3D printed cervical titanium implant. http://www.eit-spine.de/cms/en/first_cervical_individualized_ cage_implanted1/, accessed 11 Aug. 2016.

77. Man has 3D-printed vertebrae implanted in world-first surgery. http:// mashable.com/2016/02/25/3d-printed-vertebrae-spine/\#wcBd07XLOkqM, accessed 14 Aug. 2016.

78. 3D-Printed Custom-Made Hip Joint Held in Place with Stem Cells. http:// biomedical.materialise.com/blog/3d-printed-custom-made-hip-joint-heldplace-stem-cells, 14 Aug. 2016.

79. Korean Doctors Successfully Implant 3D Printed Pelvis. http://3dprinting. com/news/korean-doctors-successfully-implant-3d-printed-pelvis/, accessed 14 Aug. 2016.

80. Chang JW, Park SA, Park JK, Choi JW, Kim YS, Shin JS, Kim CH. Tissue-engineered tracheal reconstruction using three-dimensionally printed artificial tracheal graft: preliminary report. Artif Organs 2014; 38: E95-E105.

81. Masson M. Second baby's life saved with 3D printed airway splints. http:// www.engin.umich.edu/college/about/news/stories/2014/march/secondbaby-s-life-saved-with-3d-printed-airway-splints, accessed 11 Aug. 2016.

82. Ferro S. 3-D-Printed Implant Replaces 75 Percent Of Man's Skull. How long until we can successfully 3-D print a whole human? http://www.popsci.com/ science/article/2013-03/get-brand-new-skull-3-d-printing, accessed 11 Aug. 2016.

83. Molitch-Hou M. 4WEB Makes Milestone with 3,000 3D Printed Spinal Implants. http://3dprintingindustry.com/2014/11/13/3000-3d-printed-spinal-implants/?utm_source=3D+Printing+Industry+Update\&utm_mediu$\mathrm{m}=$ email\&utm_campaign=f73b7c15b9-RSS_EMAIL_CAMPAIGN\&utm_term=0_695d5c73dc-f73b7c15b9-64443961, 2014, accessed 14 Aug. 2016.

84. Transplant jaw made by 3D printer claimed as first. http://www.bbc.com/ news/technology-16907104, accessed 14 Aug. 2016.

85. Computed tomography (CT) and CT angiography. http://www.mayfieldclinic.com/PE-CT.htm, accessed 11 Aug. 2016.

86. 3D Printing of CT Data. https://www.bruker.com/imaging-blog/3d-printingof-ct-data/, accessed 11 Aug. 2016.

87. 3D Printing from MRI data in 5 steps. http://www.instructables.com/id/3DPrinting-from-MRI-data-in-5-steps/, accessed 14 Aug. 2016.

88. Researchers Develop 3D Printed Scaffolds to Cure Type 1 Diabetes. http://3dprinting.com/medical/researchers-develop-3d-printed-scaffoldsto-cure-type-1-diabetes/, accessed 14 Aug. 2016.

89. Grunewald SJ. Pfizer Scientists Turn to MakerBot to Streamline Arthritis Treatment Research. https://3dprint.com/132467/pfizer-makerbot-arthritis, accessed 14 Aug. 2016.

90. https://www.slicer.org/, accessed 14 Aug. 2016.

91. Pierwsza w Polsce Pracownia Indywidualnych Implantów Medycznych. http:// naukawpolsce.pap.pl/aktualnosci/news,379221,pierwsza-w-polsce-pracownia-indywidualnych-implantow-medycznych.html, accessed 14 Aug. 2016.

92. Czerwiński A, Frąk M. Przeszczepili fragment czaszki - ,'narysowany" w 3D, stworzony dzięki cyfrowej obrabiarce. http://lodz.wyborcza.pl/lodz/1,3513 6,14561601,Przeszczepili_fragment_czaszki_narysowany_w.html, accessed 11 Aug. 2016.

93. Zaradkiewicz J. Kości zamienne. https://www.miastoinnowacji.lodz.pl/ kosci-zamienne_16,561.html, accessed 11 Aug. 2016.

94. Prace nad wirtualną sekcją zwłok w Technoparku. http://naukawpolsce. pap.pl/aktualnosci/news,384581,prace-nad-wirtualna-sekcja-zwlok-wtechnoparku.html, accessed 23 Sept. 2016.

95. Weintraub A. 3D Systems preps for global launch of 'printed' knee implants for dogs. http://www.fiercepharma.com/animal-health/3d-systemspreps-for-global-launch-of-printed-knee-implants-for-dogs, accessed 11 Aug. 2016.

96. Bero już chodzi na czterech „łapach”. https://www.biuletyn.pw.edu.pl/Odpowiedzialna-uczelnia/Z-zycia-spolecznosci-PW/Bero-juz-chodzi-na-czterech-lapach, accessed 11 Aug. 2016.

97. Millsaps BB. Japan's Fasotec Creates Realistic 3D Printed 'Biotexture Wet Models' for Surgical Training. https://3dprint.com/49992/fasotec-3d-printwet-model/, accessed 11 Aug. 2016.

98. Virtual Surgical Planning Assists with Full Face Transplant. http:// ko.3dsystems.com/blog/2015/11/virtual-surgical-planning-assists-fullface-transplant, accessed 14 Aug. 2016.

99. Pierwszy w Polsce przeszczep twarzy przeprowadzono w Gliwicach. https://www.dawca.pl/aktualnosci/24768,pierwszy-w-polsce-przeszczeptwarzy-przeprowadzono-w-gliwicach, accessed 11 Aug. 2016.
100. World first 3D printing used in life-changing kidney transplant. http://www.guysandstthomas.nhs.uk/news-and-events/2016-news/ january/20160125-Worldfirst3Dprintingusedinlife-changingkidneytransplant.aspx, accessed 14 Aug. 2016.

101. First ever kidney transplant using 3D printing changes life of Northern Ireland toddler, Lucy, http://www.3ders.org/articles/20160126-first-kidneytransplant-using-3d-printing-changes-life-of-northern-ireland-toddler-lucy. html.

102. Surgeons Pinpoint Kidney Tumors with 3D Printed Color Models. http:// blog.stratasys.com/2015/10/19/3d-printed-kidney-model/, accessed 14 Aug. 2016.

103. Hipolite W. 3D Printing Saves a Woman's Kidney: Surgeons perform impressive renal tumor surgery. https://3dprint.com/67530/3d-printed-kidney-tumor/, accessed 11 Aug. 2016.

104. Pearson E. Conjoined twins separated in ground breaking 12 -hour operation using 3D printer technology. http://www.mirror.co.uk/news/world-news/ conjoined-twins-separated-ground-breaking-7509052, accessed 11 Aug. 2016.

105. CT and 3-D printing aid surgical separation of conjoined twins. https:// www. sciencedaily.com/releases/2015/12/151202084228.htm, accessed 11 Aug. 2016.

106. Duncan JM, Nahas S, Akhtar K, Daurka J. The use of a 3D printer in pre-operative planning for a patient requiring acetabular reconstructive surgery. J Orthop Case Rep 2015; 5: 23-25.

107. http://www.malopolskieusg.pl/en/, accessed 11 Aug. 2016.

108. Maguire A. 3D Printing Technology Leads to New Varicose Vein Treatment. http://www.healthyskinportal.com/articles/3D-Printing-TechnologyLeads-to-New-Varicose-Vein-Treatment/753/, accessed 14 Aug. 2016.

109. The First Ever Medical Winch - Zortrax M200 Contribution to Varicose Vein Surgery https://www.youtube.com/watch?v=d799V44IsX8\#xsivd, accessed 11 Aug. 2016.

110. http://poland.pl/science/achievements-science/polish-product-future/, accessed 19 Sept. 2016.

111. https://www.sculpteo.com/blog/2011/12/08/oyoglasses-make-eyewear-3dprinting-challenges-for-customized-glasses-companies/

112. Porterfield A. How to design 3d printed glasses. http://www.instructables. com/id/How-to-design-3d-printed-glasses/, accessed 14 Aug. 2016.

113. Orcutt M. 3-D Printing Breaks the Glass Barrier. https://www.technologyreview.com/s/540926/3-d-printing-breaks-the-glass-barrier/, accessed 14 Aug. 2016.

114. FDA clears 3-D printed device for minimally invasive foot surgery. http:// www.fiercemedicaldevices.com/story/fda-clears-3-d-printed-device-minimally-invasive-foot-surgery/2015-02-02, accessed 11 Aug. 2016.

115. Stinson L. Is This 3-D Printed Cast the Future of Healing Broken Bones? http://www.wired.com/2013/07/is-this-cast-the-future-of-healing-brokenbones/, accessed 11 Aug. 2016.

116. http://www.fucco3d.com/\#!druk-3d/ju363, accessed 14 Aug. 2016.

117. Murphy SV, Atala A. 3D bioprinting of tissues and organs. Nat Biotech 2014; 32: 773-785.

118. Atala A, Yoo JJ (eds.). Essentials of 3D Biofabrication and Translation. Elsevier, Amsterdam 2015.

119. Chua CK, Yeong WY. Bioprinting: Principles and Applications. World Scientific Publishing, Singapore 2015.

120. Hildreth C. How 3D Printing with Stem Cells will Alter the Future of Medicine. http://www.bioinformant.com/what-if-3d-printing-was-100x-or-1000xfaster/, accessed 11 Aug. 2016.

121. Speights K. Will 2016 Be Organovo Holdings, Inc.'s Best Year Yet? 3 reasons this 3D bioprinting company might be in for a Happy New Year. http:// www.fool.com/investing/general/2016/01/13/will-2016-be-organovo-holdings-incs-best-year-yet.aspx, accessed 14 Aug. 2016.

122. RoosterBio Inc. Launches Industry's First Ready-to-Print Stem Cell Product. http://app.getresponse.com/click.html? $x=a 62 b \&|c=2 b 3 r u \& m c=| M \& s=Q s$ D1cn\&st=BfNWv5\&u=H83W\&y=T\&, 2016, accessed 14 Aug. 2016.

123. http://www.cellink.eu/, accessed 11 Aug. 2016.

124. http://www.roosterbio.com/, accessed 11 Aug. 2016.

125. Printing Skin Cells on Burn Wounds. www.wakehealth.edu/Research/ WFIRM/Research/Military-Applications/Printing-Skin-Cells-On-BurnWounds.htm, accessed 11 Aug. 2016.

126. de Mel A. 3D Printing Soft Tissue as Surgical Implants. www.sme.org/uploadedFiles/EuroMold/deMel.pdf, accessed 11 Aug. 2016.

127. Scott C. University of California San Diego's 3D Printed Liver Tissue May Be the Closest We've Gotten to a Real Printed Liver. https://3dprint. com/118932/uc-san-diego-3d-printed-liver/, accessed 11 Aug. 2016.

128. How do they 3D print kidney in China. http://www.3ders.org/articles/20130815how-do-they-3d-print-kidney-in-china.html, accessed 11 Aug. 2016. 
129. Quigley JT. Chinese Scientists Are 3D Printing Ears and Livers - With Living Tissue. http://thediplomat.com/2013/08/chinese-scientists-are-3d-printing-ears-and-livers-with-living-tissue/, 2013, accessed 14 Aug. 2016.

130. CT-Bone ${ }^{\circledR}$ : real bone from the 3D Printer. www.xilloc.com/ct-bone/, accessed 11 Aug. 2016.

131. Herkewitz W. Incredible 3D Printer Can Make Bone, Cartilage, and Muscle. http://www.popularmechanics.com/science/health/a19443/3d-printerbone-cartilidge-and-muscle/, accessed 11 Aug. 2016.

132. Grunewald SJ. New Self-Healing Bio-Glass May Be Used as 3D Printed Cartilage Replacements. https://3dprint.com/134070/3d-print-cartilagereplacement/, accessed 11 Aug. 2013.

133. Halterman TE. https://3dprint.com/58602/3d-printed-heart-organoid/, 2015, accessed 14 Aug. 2016.

134. DR ANTHONY ATALA - Making 3-D Organs, Body Parts, Printing Technologies and More (Version 1). https://www.youtube.com/watch?v=tyGQ4NLgqaE, accessed 14 Aug. 2016

135. Mole BM. Scientists print self-assembling 'living tissue'. http://www. nature.com/news/scientists-print-self-assembling-living-tissue-1.12743, 2015, accessed 14 Aug. 2016

136. Wakefield J. TED 2013: 4D printed objects 'make themselves'. http://www. bbc.com/news/technology-21614176, 2013, accessed 11 Aug. 2016.

137. Kang HW, Lee SJ, Ko IK, Kengla C, Yoo JJ, Atala A. A 3D bioprinting system to produce human-scale tissue constructs with structural integrity. Nat Biotechnol 2016; 34: 312-319.

138. Organovo Announces Commercial Release of the exVive3D ${ }^{\mathrm{TM}}$ Human Liver Tissue. http://www.marketwatch.com/story/organovo-announcescommercial-release-of-the-exvive3dtm-human-liver-tissue-2014-11-18, accessed 11 Aug. 2016.

139. Nguyen DG, Funk J, Robbins JB, Crogan-Grundy C, Presnall SC, Singer T, Roth AB. http://dx.doi.org/10.1371/journal.pone.0158674, 2016, accessed 14 Aug. 2016

140. L'Oreal to start 3D-printing skin. http://www.bbc.com/news/technology32795169, accessed 11 Aug. 2016.
141. Sher D. Exclusive: CELLINK's \$5,000 3D Bioprinter Is Making the INKREDIBLE... Credible. http://3dprintingindustry.com/news/cellink-new-3d-bioprinter-is-making-the-inkredible-credible-56733/, 2015, accessed 14 Aug. 2016.

142. BioPen to rewrite orthopaedic implants surgery. http://media.uow.edu.au/ news/UOW162803.html, accessed 14 Aug. 2016

143. Chinese Scientists Are 3D Printing Ears and Livers - With Living Tissue. (143) http://thediplomat.com/2013/08/chinese-scientists-are-3d-printing-ears-and-livers-with-living-tissue/, accessed 11 Aug. 2016.

144. Frey T. Inventing the 3D Pill Printer. http://www.futuristspeaker.com/business-trends/inventing-the-3d-pill-printer/, 2012, accessed 11 Aug. 2016.

145. Luimstra J. Why There Are Two Sides to 3D Printed Drugs. http://3dprinting com/medical/3d-printing-drugs/, 2014, accessed 14 Aug. 2016.

146. Dodziuk H. What's New in 3D Printing? http://www.chemistryviews.org/ details/ezine/5736441/Whats_New_in_3D_Printing.html, 2014, accessed 14 Aug. 2016.

147. Mearian L. http://www.computerworld.com/article/3048823/3d-printing/ this-is-the-first-3d-printed-drug-to-win-fda-approval.html, 2016, accessed 14 Aug. 2016.

148. Palmer E. Company builds plant for 3DP pill making as it nails first FDA approval. http://www.fiercepharma.com/regulatory/company-builds-plantfor-3dp-pill-making-as-it-nails-first-fda-approval, accessed 14 Aug. 2016.

149. Personalized medicine. https://en.wikipedia.org/wiki/Personalized_medi cine, accessed 14 Aug. 2016.

150. Speights K. Will 2016 Be Organovo Holdings, Inc.'s Best Year Yet? 3 reasons this 3D bioprinting company might be in for a Happy New Year. http:// www.fool.com/investing/general/2016/01/13/will-2016-be-organovo-holdings-incs-best-year-yet.aspx, 2016, accessed 14 Aug. 2016.

151. About the NIH 3D Print Exchange. http://3dprint.nih.gov/about, accessed 14 Aug. 2016.

52. Basiliere P. Gartner Predicts 2016: 3D Printing Disrupts Healthcare and Manufacturing. http://blogs.gartner.com/pete-basiliere/2015/12/02/gartner-predicts-2016-3d-printing-disrupts-healthcare-and-manufacturing/, 2015, accessed 14 Aug. 2016. 